\title{
Habitat use by vicuña Vicugna vicugna in Laguna Pozuelos Reserve, Jujuy, Argentina
}

\author{
Yanina Arzamendia, Marcelo H. Cassini and Bibiana L. Vilá
}

\begin{abstract}
Vicuña Vicugna vicugna are an emblematic species of one of the major arid ecosystems of the neotropics: the puna or altiplano. Excessive commercial hunting of vicuña for their valuable fleece in the past caused a severe decline in the population, with the vicuña almost becoming extinct by the mid 20th century. Effective protection resulted in the recovery of some populations and, recently, limited vicuña exploitation has been allowed. Research is urgently required to underpin the design of the management systems used for this exploitation. We present the results of a 2-year study on habitat utilization of vicuña in Laguna de Pozuelos UNESCO Biosphere Reserve in Argentina. Vicuña did not use the study area homogeneously but preferred vegetation communities dominated by grasses (known
\end{abstract}

locally as pajonal and esporal) and with high overall plant cover. Vicuña were less selective in 2003, when overall habitat quality decreased, than in 2002. This change is predicted by habitat selection theory. We also found that members of family groups spend more time foraging than members of non-reproductive groups. Solitary vicuña spend more time standing up than members of groups, consistent with the observation that herding behaviour is related to protection against predators. Heterogeneous use and habitat selectivity suggest that exploitation of vicuña needs to take spatial behaviour into account in the establishment of the optimal location of capturing sites.

Keywords Argentina, habitat use, Jujuy, Pozuelos Reserve, sustainable use, Vicugna vicugna, vicuña.

\section{Introduction}

The vicuña Vicugna vicugna is a wild South American camelid that inhabits the puna or altiplano region (3,0004,700 m altitude) of Perú, Bolivia, Chile and Argentina (Koford, 1957). Excessive commercial hunting of vicuña for their valuable fleece caused a severe decline in the population, almost to the point of extinction, by the mid 20th century. Effective protection, however, resulted in the recovery of some populations (Torres, 1992), and vicuña are now categorized as Lower Risk/conservation dependent on the IUCN Red List (IUCN, 2004).

In Argentina there are approximately 35,000-40,000 vicuña (Lichteinstein \& Vilá, 2003) in the north-western provinces of Jujuy, Salta, Catamarca, La Rioja and San Juan. Argentine vicuña populations are on Appendix I of CITES, with the exception of those of Jujuy and Catamarca provinces, which were listed on Appendix II

Yanina Arzamendia Organización FUNDANDES, Avda. San Pedro y San Pablo 692, 4600 San Pablo de Reyes, Jujuy, Argentina.

Marcelo H. Cassini ${ }^{\star}$ (Corresponding author) and Bibiana L. Vilá Universidad Nacional de Luján, Rutas 5 y 7, 6700 Luján, Argentina.

E-mail mcassini@mail.unlu.edu.ar

*Also at: Organización PROFAUNA, Corrientes 1145, 4 of 46, 1043 Buenos Aires, Argentina.

Received 6 September 2004. Revision requested 25 January 2005 Accepted 10 June 2005 of CITES in 1997 and 2003, respectively (CITES, 2005). Several projects that involve the capturing and shearing of free-living vicuña have been initiated in both provinces. However, studies of key aspects of vicuña ecology are required to evaluate and, where necessary, minimize the impact of utilization and ensure sustainability of the populations.

One of these key aspects of vicuna ecology is habitat use. Previous studies, for example in Pampa Galeras Reserve, Perú (Franklin, 1983), and Laguna Blanca, Catamarca Province, Argentina (Renaudeau d'Arc et al., 2000), showed that vicuña use only a small proportion of their potential habitat in protected areas. This heterogeneous habitat use implies that the actual resources available for vicuña are significantly smaller than may be estimated by considering the reserve as a whole.

In this paper we present the result of a 2-year study on habitat utilization by vicuña in a protected area in Argentina. This study is part of the Cieneguillas Case Study in Proyecto MACS (Sustainable economic utilization of wild South American camelids). The objective is to develop science-based management plans for the wild management of vicuña, enhance cooperation between scientists and local communities, and design techniques for capture and shearing that provide economic returns, ensure a sustainable vicuña population, and have low environmental impact. The ultimate aim is to balance income generation with ecological sustainability. 


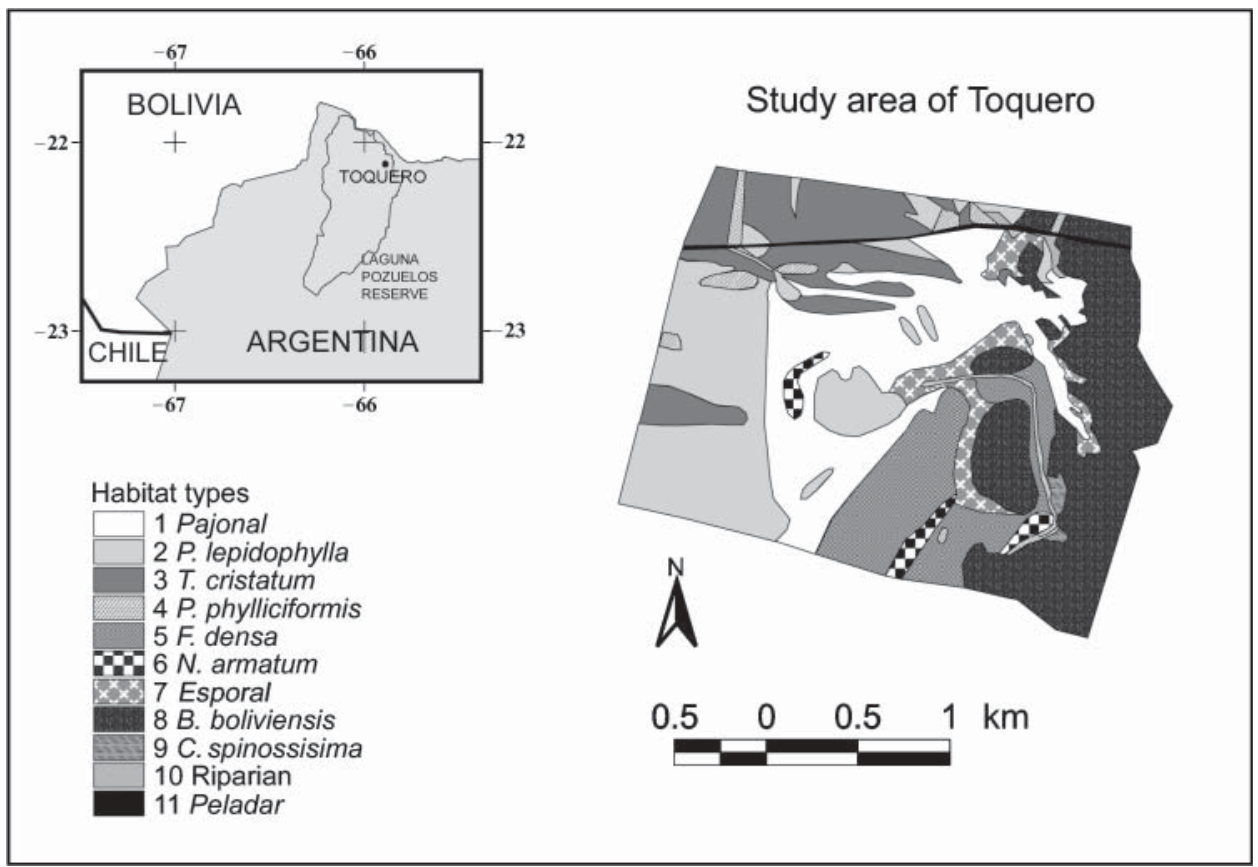

Fig. 1 The location of the Laguna Pozuelos Reserve in Argentina (inset) and the study area of Toquero with the distribution of the 11 identified habitat types (Table 1, see text for details).

\section{Study area}

The study area was in Toquero (800 ha, at elevations of 3,600-3,800 m), which is part of the Laguna de Pozuelos UNESCO Biosphere Reserve, Jujuy, Argentina (Fig. 1). The climate is extreme, with large diurnal fluctuations in temperature and frequent frosts. Rain falls mainly in December-March. Strong, dry winds are frequent. Soils are stony, sandy or saline. The reserve includes the puna and altoandino phytogeographic provinces (Cabrera, 1957). The closest meteorological station to the study area is at Mina Pirquitas, $93 \mathrm{~km}$ from Toqueros, which received a total rainfall of 147.0 and $2.5 \mathrm{~mm}$ in 2002 and 2003, respectively.

\section{Methods}

By the interpretation of 1:45000 aerial photographs we classified the study area into 11 habitat types (Table 1) distinguished by vegetation physiognomy and dominant plant species (Matteucci \& Colma, 1982). We made 15 field trips from 16 April 2002 to 31 October 2003, covering all seasons. Data were collected from a high fixed point, between 07.00 and 19.00. On each of 43 days we used binoculars to scan the whole study area six times, on average, each time for 1 hour, for a total of 253 hours of observations (121 and 132 in 2002 and 2003, respectively). We also continued observations between scans. The daily observation period was divided into four time periods (07.00-10.00, 10.00-13.00, 13.00-16.00, 16.00-19.00) and scans were distributed evenly between these periods. The following variables were recorded for each group of vicuña: location, behaviour of most members of the group, type and size of group (Altman, 1974; Martin \& Bateson, 1986).

The area of each of the 11 habitat types was determined from locations taken with a geographical positioning system. Within each habitat type $2 * 2$ m quadrats (following Matteuchi \& Colma, 1982) were surveyed, in each season, for vegetation composition, height, cover and dominance. There were 105 quadrats in total, with the number in each habitat type proportional to its area.

Habitat use was determined by the frequency with which groups of vicuña were observed in each habitat type during the 253 hours of observation, and habitat availability was the proportion of the area occupied by each vegetation community. Habitat selection was analysed using the methodology of Manly et al. (1993) in which the relationship between the use of a resource and its availability are combined in a selection index that is compared using a log-likelihood $\chi^{2}$ test. The selection index was calculated as $a=r_{i} / n_{i}\left(1 /\left(\Sigma r_{j} / n_{j}\right)\right)$, where $r_{i}$ and $r_{j}$ are proportions of prey type $i$ or $j$ in diet, and $n_{i}$ and $n_{j}$ are proportions of prey types $i$ or $j$ in the environment. The $a$ values are normalized so that the sum of all values equals 1 . When selective feeding does not occur $a$ is equal to the inverse of the total number of food types. Bonferroni confidence intervals were estimated to evaluate the significance of each index (Manly et al., 1993). The effects of environmental variables on the number of vicuña were analysed using general linear models (GLM) with type III sum of squares, which are the most robust for unbalanced designs. 
Table 1 The 11 habitat types identified in the study area of Toquero (Fig. 1), with the area, associated species and total percentage cover of vegetation.

\begin{tabular}{|c|c|c|c|}
\hline Habitat type & Area (ha) & Associated species & Total cover $(\%)$ \\
\hline $\begin{array}{l}1 \text { Pajonal }^{*} \text {, dominated by tall grasses } \\
\text { (Festuca spp.) }\end{array}$ & 223 & $\begin{array}{l}\text { Parastrephia lepidophylla, with a low stratum of } \\
\text { Adesmia sp., Aristida sp. \& Boutelowa simplex }\end{array}$ & $50-80$ \\
\hline 2 Shrub steppe of P. lepidophylla & 195 & $\begin{array}{l}\text { The grass Stipa neesiana \& the shrub Tetraglochin cristatum, } \\
\text { with a low stratum of grasses such as B. simplex, } \\
\text { Aristida sp. \& Cynodon sp. }\end{array}$ & $50-80$ \\
\hline 3 Shrub steppe of T. cristatum & 133 & Aristida sp. \& Adesmia sp. in the lower stratum & $20-45$ \\
\hline $\begin{array}{l}4 \text { Shrub steppe of Parastrephia } \\
\text { phylliciformis }\end{array}$ & 0.5 & $\begin{array}{l}\text { Tall (Festuca sp.) \& short grasses (Mulembergia sp. \& } \\
\text { Alchemilla sp.) }\end{array}$ & $85-90$ \\
\hline 5 Shrub steppe of Fabiana densa & 40 & Baccharis incarum \& Adesmia sp. & $50-70$ \\
\hline 6 Shrub steppe of Nardophyllum armatum & 15 & Adesmia sp., Ephedra sp., B. incarum \& T. cristatum & $20-40$ \\
\hline 7 Esporal $^{*}$, dominated by Penissetum chilense & 29 & Festuca sp. \& P. lepidophylla & $30-50$ \\
\hline $\begin{array}{l}8 \text { Shrub steppe of Baccharis boliviensis, } \\
\text { on mountain slopes }\end{array}$ & 151 & Grass (Stipa sp.) \&/or shrubs (Adesmia sp. \& T. cristatum) & $15-30$ \\
\hline $\begin{array}{l}9 \text { Shrub steppe of Colletia spinossisima on } \\
\text { the steepest slopes }\end{array}$ & 2 & & 50 \\
\hline 10 Riparian & 10 & $\begin{array}{l}\text { Groves of Cortaderia speciosa, small swamp areas with dense, } \\
\text { low vegetation \& grassland of Deyeuxia sp. \& Mulembergia sp. }\end{array}$ & $60-85$ \\
\hline $\begin{array}{l}11 \text { Peladar*, open rocky areas at the edges of } \\
\text { roads with B. simplex and Aristida sp. }\end{array}$ & 2 & & $10-60$ \\
\hline
\end{tabular}

*Local names for these habitat types.

\section{Results}

In a GLM analysis with number of vicuña per scan as the dependent variable and year and habitat types as independent variables (Fig. 2) there were no significant differences in number of vicuña between years $\left(F_{1,2761}=\right.$ 2.34, $\mathrm{P}=0.126)$, but there were significant differences $\left(F_{10,2761}=272.5, \mathrm{P}<0.0001\right)$ in the use of habitat types. The interaction term (year * habitat type) was highly significant $\left(F_{10,2761}=7.5, \mathrm{P}<0.0001\right)$, indicating that the habitat use of vicuña was different between years.

The comparison between habitat use and availability, using the method of Manly et al. (1993), indicated that vicuña were selective in their use of habitat types in both years $\left(\chi^{2}{ }_{10}=44.3\right.$ and $\chi^{2}{ }_{10}=61.8$, for 2002 and 2003, respectively, $\mathrm{P}<0.01)$. However, statistical analysis of the selectivity indices for each habitat type using Bonferroni confidence intervals indicated that vicuña were more selective in their habitat use in 2002 than in 2003. In 2002 the mean percentage of vegetation cover per habitat $(53.3 \%)$ was significantly higher (paired $t$-test, $\left.t_{11}=8.2, \mathrm{P}<0.0001\right)$ than in $2003(46.1 \%)$. There was a significant positive correlation $\left(r^{2}=0.38, \mathrm{P}=0.04\right)$ between the selectivity index and percentage of vegetation cover of vegetation types, suggesting that vicunas more intensively used those habitats with greater abundance of vegetation.

In a GLM analysis with number of vicuña per scan as the dependent variable and season (spring, summer, autumn, and winter) and time period as independent variables (Fig. 3) season was non-significant $\left(F_{3,119}=2.30\right.$,
$\mathrm{P}=0.08)$. Time period was highly significant $\left(F_{3,119}=\right.$ 13.71, $\mathrm{P}<0.0001$ ) and there was generally an increase of vicuña in the study area as the day progressed. The interaction term (season * hour) was non-significant $\left(F_{10,2761}=0.99, \mathrm{P}=0.44\right)$, but vicuña appeared to arrive in the study area earlier in winter than in summer.

As the behaviour of vicuna was sampled by group and not by individual, a two-way contingency analysis was conducted with absolute frequency of groups as the dependent variable and type of group (family, bachelors or solo vicuña) and behaviour (forage, walk, social/maintenance, run, stand and lie) as grouping factors (Fig. 4). This was highly significant $\left(\chi_{10}^{2}=179.5\right.$, $\mathrm{P}<0.0001$ ), suggesting that the occurrence of behaviours differed between groups. Bachelors groups and solo vicuña foraged less and moved more than vicuña in family groups. Solo animals were more frequently observed standing up than members of groups.

\section{Discussion}

During 2 years of study in the Toqueros area of the Laguna Pozuelos Reserve vicuña did not use the study area homogeneously. They spent more time in habitats dominated by grasses (pajonal and esporal) and with high overall plant cover than in habitats with low cover dominated by bushes such as $P$. lepidophylla and $B$. incarum (with poor digestibility) or Tetraglochin cristatum (an indicator of grassland degradation; Alzerreca, 2003).

The preference of vicuña for habitats dominated by grasses and with high plant cover has been noted 


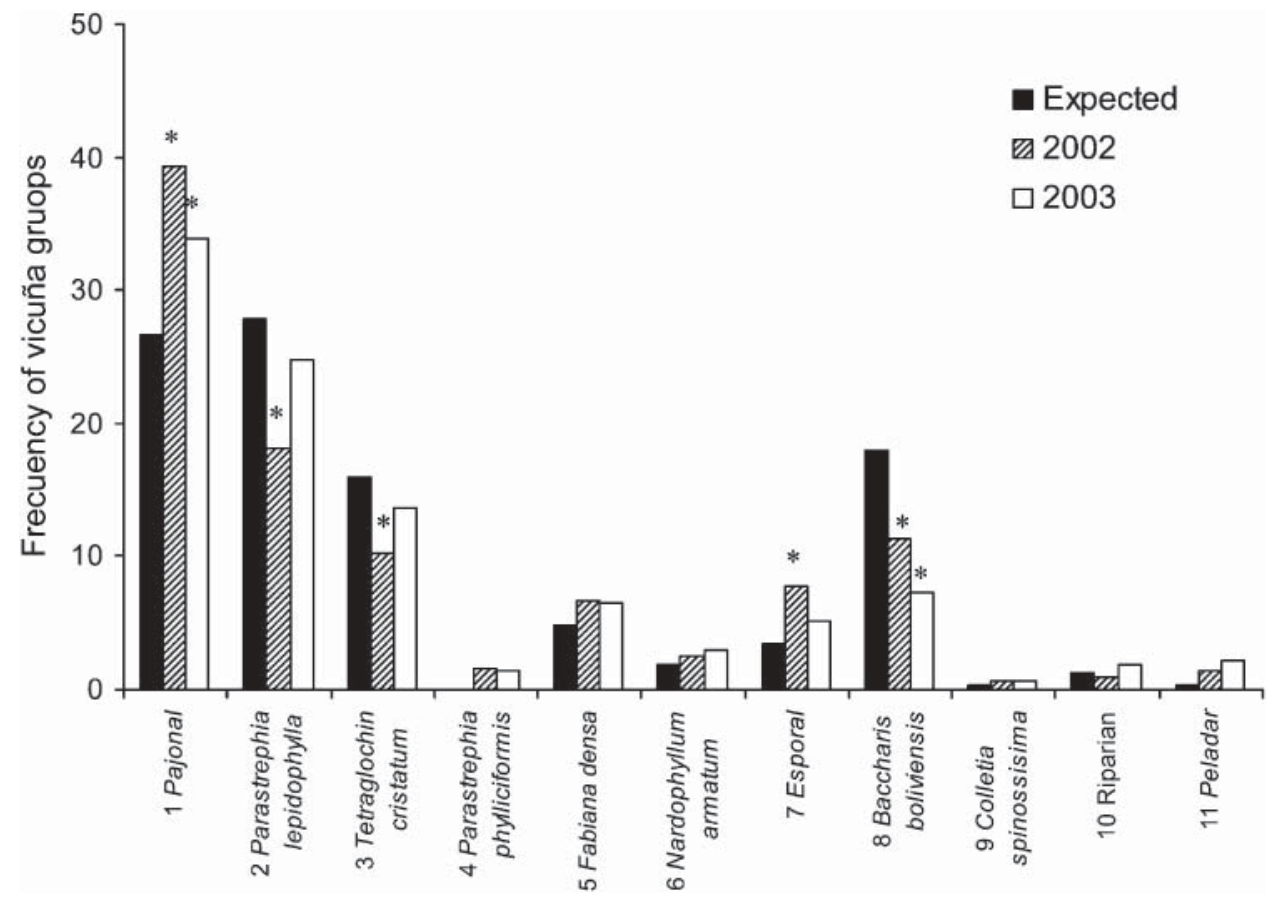

Fig. 2 Actual and expected frequencies of groups of vicuña observed during 2002-2003 in the 11 habitat types (Table 1) of Laguna Pozuelos Reserve. *Indicates $\mathrm{P}<0.05$ for Bonferroni confidence intervals of the selectivity index (see text for details).

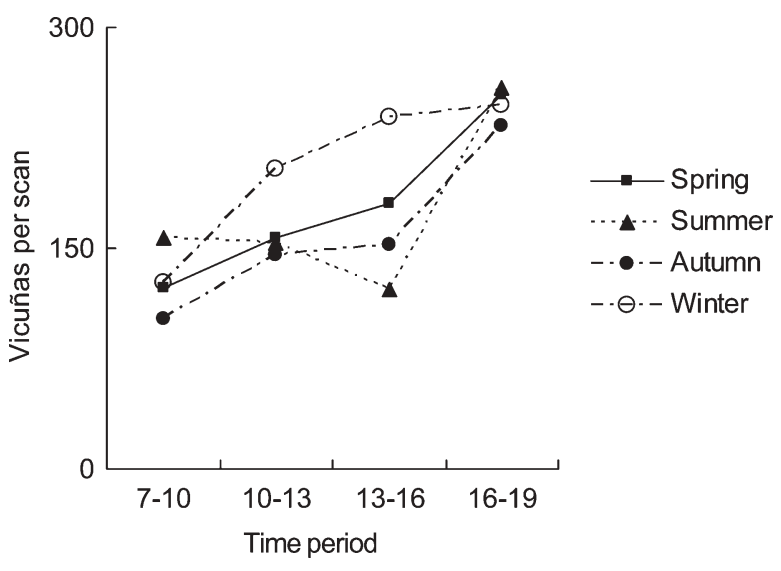

Fig. 3 Mean numbers of vicuña observed per scan at different time periods during the day in each season.

elsewhere. In Pampas Galeras, Perú, vicuña prefer to forage in grass steppe dominated by either Festuca rigesens or Calamagrostis vicunarum, or in vegas, a type of wetland (Franklin, 1983). Vegas are composed of plants that grow close to the ground, with high ground cover and biodiversity, and deep, wet topsoil. Of the two main habitats in Ulla-Ulla, Bolivia (grass steppe and vegas), vicuña prefer vegas, although the availability of this habitat for vicuña depended on the presence of people and alpacas (Villalba, 2003). Of the three main habitats in San Guillermo Reserve, Argentina (plains with tussock grassland, gentle grassy slopes, and rocky slopes), vicuña are more abundant in the grassland plains and

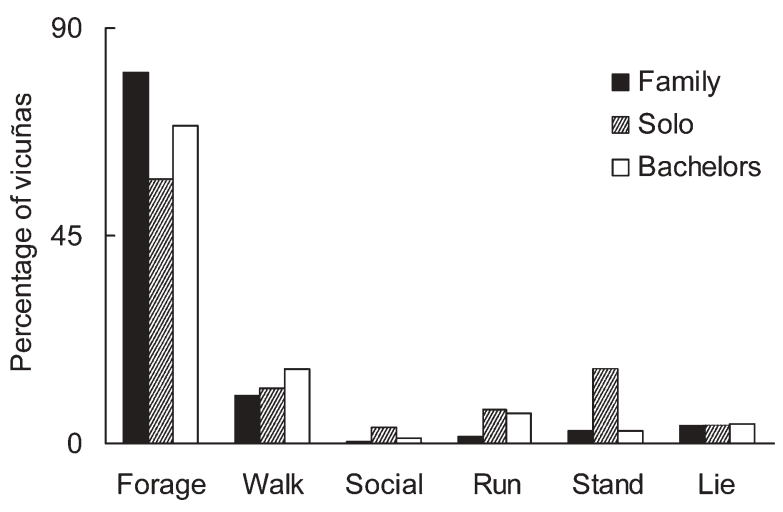

Fig. 4 Percentage of group types (family, bachelor groups and solitary individulas) of vicuña exhibiting different behaviours.

there is a positive correlation between vicuña density and plant cover (Cajal, 1989). This preference for grassland steppes and vegas is consistent with the known preference of vicuña for Poaceae and Cyperaceae (Koford, 1957; Franklin, 1983; Cajal, 1989; FIDA, 1991; Aguilar et al., 1999).

The change in habitat selectivity that we observed between years is a temporal pattern that has not been previously described for vicuña. Because the number of individuals did not vary between years, the reduction in selectivity observed from 2002 to 2003 implies a change in vicuña distribution between plant communities. In 2002 we found that availability of vegetation (grossly 
estimated from plant cover) was higher than in 2003 (a dry year) for all habitat types. Habitat selection theory predicts that when resources are concentrated in good habitats most individuals will use these habitats, but when the availability of resources decreases in good habitats, less competitive individuals will move to low quality habitats (Sutherland, 1996). The result is a more homogeneous distribution between habitats, as we observed in 2003. This intensity of this phenomenon, known as the buffer effect, depends on the nature of intraspecific competition (Gill et al., 2001).

Bonacic et al. (2002) recognized the role of competition in the population ecology of vicuña. They found evidence of density dependence and suggested that longterm density-dependent relationships are modulated by between year changes in precipitation and food availability. Our results suggest that the buffer effect is a possible spatial mechanism that mediates density-dependency in vicuña. Our other findings confirmed the results of earlier studies of vicuña in Argentina, with daily changes in activity (Vilá \& Roig, 1992; Renaudeau d'Arc et al., 2000) and with members of family groups (mostly females with calves) spening more time foraging than non-reproductive groups (Vilá \& Cassini, 1993).

Solitary vicuña spent more time standing up than members of groups. This posture is normally used for vigilance and implies a cost in terms of reduction in foraging time (Vilá \& Cassini, 1994). This negative trend between vigilant behaviour and group size has repeatedly been found in species where group formation is associated with predator defence (Krause \& Ruxton, 2002). Behavioural ecology theory postulates that one selective pressure for the evolution of group formation is the benefit obtained from the vigilant behaviour of other members of the group, which permits an increase in time spent foraging (Krause \& Ruxton, 2002).

The vicuña of Jujuy province are the subject of a number of existing and planned projects for in situ and ex situ commercial exploitation. In particular, the area under study has become a management area for wild vicuña in which the prehispanic chaku method (Custred, 1979), which consists of a drive, capture, shearing and release of wild vicuña, is operated within a modern animal welfare framework (Bonacic \& MacDonald, 2003). It is important that sound science underlies management because sustainable exploitation must take biological and ecological principles into account (Taylor \& Dunstone, 1996). The data presented here on vegetation, habitat use, vegetation preferences and daily activities helped us to plan the location and structure of the capture facilities for vicuña in Toquero. We believe this is the first instance in which such research has been carried out prior to the capture of vicuña for sustainable use. The research was designed to provide a baseline for comparisons after management had commenced, and will help us to evaluate the biological impact of management, especially in the long-term.

\section{Acknowledgements}

We thank Asociación Los Pioneros de Cieneguillas, especially the Maidana family, who give us the permission to work in their fields and provided logistic support. The Argentinean National Research Council (CONICET), the Agencia Nacional de Promoción Científica and Tecnológica, the Universidad Nacional de Luján and Proyecto MACS provided financial support. MACS is cocoordinated by Professor Iain Gordon, Macaulay Institute, Aberdeen, UK, and supported by the INCO II Programme of the European Commission, DG Research (ICA4-2000-10229).YA thanks Jorge Baldo, Diego Baldo, Sandra Romero and Hugo Lamas for field assistance, Dora Vignale for vegetation identification, and Valeria Hamity and Alejandra Caro for assistance with maps.

\section{References}

Aguilar, M.G., Chagra Dib, E.P. \& Neumann, R. (1999) Rangeland in the diet of vicugnas. In Progress in South American Camelids Research (eds M. Gerken \& C. Renieri), pp. 329-333. EAAP, Göttingen, Germany.

Altmann, J. (1974) Observational study of behaviour: sampling methods. Behaviour, 49, 227-267.

Alzerreca, H. (2003) Recuperación de la vegetación forrajera en habitats de camélidos en los andes de Bolivia. In Memorias del III Congreso Mundial sobre Camélidos, 1er. Taller internacional de DECAMA, Volume I (eds Centro de Investigacion y Forrajes 'La Violeta, Facultad de Ciencias Agrícolas y Pecuarias, Universidad Mayor San Simon), pp. 41-54. Potosí, Bolivia.

Bonacic, C. \& Macdonald, D.W. (2003) The physiological impact of wool-harvesting procedures in vicuñas (Vicugna vicugna). Animal Welfare, 12, 387-402.

Bonacic, C., Macdonald, D.W., Galaz, J. \& Sibly, R.M. (2002) Density dependence in the camelid Vicugna vicugna: the recovery of a protected population in Chile. Oryx , 36, 118-125.

Cabrera, A.L. (1957) La vegetación de la Puna Argentina. Revista de Investigaciones Agrícolas, 4, 317-412

Cajal, J. (1989) Uso de habitat por vicuñas y guanacos enla Reserva San Guillermo, Argentina. Vida Silvestre Neotropical $2,21-31$.

CITES (2005) Appendices I, II and III. Convention on International Trade in Endangered Species of Wild Fauna and Flora. CITES Secretariat, Geneva, Switzerland [http:/ / www.cites.org/ esp/app/appendices.shtml, accessed 24 March 2006].

Custred, G. (1979) Hunting technologies in Andean culture. Journal de la Société des Americanistes, 66, 7-12.

FIDA (1991) Programa Regional de apoyo al desarrollo de la crianza de camélidos Sudamericanos (Argentina, Bolivia, Chile, Ecuador y Perú): La crianza de camélidos y características de la producción. Annex IV. Report 0334. Fondo Internacional de Desarrollo Agrícola (FIDA), La Paz, Bolivia. 
Franklin, W.L. (1983) Contrasting socioecologies of South America's wild camelids: the vicuña and the guanaco. In Advances in the Study of Mammalian Behaviour (eds S.F. Eisenberg \& D.G. Kleinman), pp. 573-629. Special Publication No. 7, ASM, Shippensburg, USA.

Gill, J.A., Norris, K., Potts, P.M., Gunnarsson, T.G., Atkinson, P.W. \& Sutherland, W.J. (2001) The buffer effect and large-scale population regulation in migratory birds. Nature, 412, 436-438.

IUCN (2004) IUCN Red List of Threatened Species. IUCN, Gland, Switzerland [http:/ /www.redlist.org, accessed 5 September 2005].

Koford, C.B. (1957) The vicuna and the puna. Ecological Monographs, 27, 153-219.

Krause, J. \& Ruxton, G.D. (2002) Living in Groups. Oxford University Press, Oxford, UK.

Lichteinstein, G. \& Vilá, B.L. (2003) Vicuña use by Andean communities: an overview. Mountain Research \& Development, 23, 198-202.

Manly, B.F.J., McDonald, L.L. \& Thomas, D.L. (1993) Resource Selection by Animals: Statistical Design and Analysis for Field Studies. Chapman \& Hall, London, UK.

Martín, P. \& Bateson, P. (1986) Measuring Behaviour. An Introductory Guide. Cambridge University Press, Cambridge, UK.

Matteuchi, S. \& Colma, A. (1982) Metodologías para el estudio de la vegetación. Organización Estados Americanos, Washington, DC, USA.

Renaudeau D’Arc, N., Cassini, M. \& Vilá, B.L. (2000) Habitat use of vicunas in Laguna Blanca Reserve (Catamarca, Argentina). Journal of Arid Environments, 46, 107-115.

Sutherland, W.J. (1996) From Individual Behaviour to Population Ecology. Oxford University Press, Oxford, UK.

Taylor,V.J. \& Dunstone, N. (1996) The Exploitation of Mammal Populations. Chapman \& Hall, London, UK.

Torres, H. (1992) South American Camelids: An Action Plan for their Conservation. IUCN/SSC South American Camelids Specialist Group, Gland, Switzerland.
Vilá, B.L. \& Cassini, M.H. (1993) Summer and autumn activity patterns of vicuña. Studies on Neotropical Fauna $\mathcal{E}$ Environment, 28, 251-258.

Vilá, B.L. \& Cassini, M.H. (1994) Time allocation during the reproductive season in vicuñas. Ethology, 97, 226-235.

Vilá, B.L. \& Roig, V.G. (1992) Diurnal movements, family groups and alertness of vicuna (Vicugna vicugna) during the late dry season in the Laguna Blanca Reserve

(Catamarca-Argentina). Small Ruminant Research, 7, 289-297.

Villalba, L. (2003) Uso de habitat e interacciones entre la vicuña y la alpaca en la reserva nacional de fauna Ulla-Ulla, Bolivia. In Memorias del III Congreso Mundial sobre Camélidos, 1er. Taller internacional de DECAMA, Volume I (eds Centro de Investigacion y Forrajes 'La Violeta, Facultad de Ciencias Agrícolas y Pecuarias, Universidad Mayor San Simon), pp. 205-210. Potosí, Bolivia.

\section{Biographical sketches}

Yanina Arzamendia is a researcher with Proyecto MACS. Her research is part of a programme conducted by an interdisciplinary group with the aim of establishing a baseline of knowledge for the development of a system of conservation and sustainable use of South American wild camelids.

Marcelo H. Cassini specializes in the ecology and behaviour of mammals. He is involved in projects on the conservation of endangered species, sustainable use of species with commercial value, control of invasive species and design of protected areas.

Bibiana L. Vilá is responsible for Proyecto MACS in Argentina. She has been working on vicuña ecology and behaviour since 1985 and is now looking at the sustainable use of wild vicuña and environmental education in the puna communities. 